\title{
Obstructs-equipped apparatus reduces cannibalism and improves larval survival of the Coccinellid, Harmonia axyridis (Coleoptera: Coccinellidae)
}

\author{
Yuan-Xing Sun ${ }^{1,2^{*}}$ (D), Ya-Nan Hao ${ }^{1,2}$, Chang-Zhong Liu ${ }^{1,2}$, Jing-Jiang Zhou ${ }^{1,2}$ and Sen-Shan Wang ${ }^{1,2}$
}

\begin{abstract}
Background: Harmonia axyridis (Pallas) (Coleoptera: Coccinellidae) is an important biocontrol agent in native region of Asia, while its high propensity for cannibalism causes great obstacles in mass production. Provisioning obstructs in rearing containers could decrease the cannibalism of ladybird beetles. In this study, three different patterns of obstructs (Con-A, Con-B, and Con-C) were designed and equipped in plastic Petri dishes $\left(95.38 \mathrm{~cm}^{3}\right.$ ) as rearing units, and their efficiency for $\mathrm{H}$. axyridis larval survival was tested. The potential of the high-density rearing was then evaluated using the optimal units with 16, 24, or 32 larvae per unit (named 16-L, 24-L, or 32-L, respectively).

Results: Larval survivals in obstructs-equipped units were generally higher than those in control, and significantly increased with the Con-C units (39.8\% versus $74.2 \%$ at adult stage). With the Con-C units, the survivals were significantly higher at $16-\mathrm{L}$ density (82.5\%) than those at 24-L density (62.5\%), but both were non-significantly different from those at 32-L density (70.0\%). The weights of newly emerged adults (fit with the expected sex ratio of 1:1) at the higher densities were lower than those at 16-L density.

Conclusions: The results demonstrate that $H$. axyridis can be reared at a higher density $\left(\approx 0.336\right.$ larvae $\left./ \mathrm{cm}^{3}\right)$ in a constrained unit and highlight the effects of obstructs in reducing cannibalism and improving insect survivals.
\end{abstract}

Keywords: Harmonia axyridis, Cannibalism, Mass rearing, Larval survival, Obstructs

\section{Background}

Biological control approaches are well-established methodologies for the control of pest population in some agricultural systems (Mills and Heimpel 2018). Among them, the augmentative type is shown to play a great role in reducing pesticide use (van Lenteren and Bueno 2003), and its typical feature is the mass releasing of natural enemies into infested field to obtain an immediate control of pests (van Lenteren 2012). In this type of pest management system, space-saving in rearing natural

\footnotetext{
* Correspondence: sunyx1988@126.com

'College of Plant Protection, Gansu Agricultural University, Lanzhou, Gansu 730070, People's Republic of China

${ }^{2}$ BioControl Engineering Laboratory of Crop Diseases and Pests of Gansu Province, Lanzhou, Gansu 730070, People's Republic of China
}

enemies and maximizing of rearing density are vital to meet the quantity demand (Riddick and Wu 2015). More importantly, optimal rearing density in suitable units can decrease the maintenance cost (Mamay and Mutlu 2019). This is more crucial for the natural enemies that have cannibalism behaviors. Cannibalism, a common behavior in Coccinellidae (Osawa 2002), has been identified as a key factor for the population dynamics, and a major problem in the mass-rearing of coccinellid species (Obrycki and Kring 1998).

The multicolored Asian ladybird beetle, Harmonia axyridis (Pallas) (Coleoptera: Coccinellidae), a notorious aggressive invasive species (Roy et al. 2016), is an important augmentation biological control agent in the native distribution region of Asia (Brown et al. 2008).

\section{Springer Open}

(0) The Author(s). 2021 Open Access This article is licensed under a Creative Commons Attribution 4.0 International License, which permits use, sharing, adaptation, distribution and reproduction in any medium or format, as long as you give appropriate credit to the original author(s) and the source, provide a link to the Creative Commons licence, and indicate if changes were made. The images or other third party material in this article are included in the article's Creative Commons licence, unless indicated otherwise in a credit line to the material. If material is not included in the article's Creative Commons licence and your intended use is not permitted by statutory regulation or exceeds the permitted use, you will need to obtain permission directly from the copyright holder. To view a copy of this licence, visit http://creativecommons.org/licenses/by/4.0/. 
Earlier studies demonstrated that $H$. axyridis larvae had a stronger cannibalism behavior than many other aphidophagous ladybirds and was independent from prey abundance (Reznik et al. 2017) but increased with larval density (Michaud 2003). In field, the mortality of 4th instar larvae $(93.30 \%)$ was higher than those of the other stages (less than 50.51\%) due to the food storage and cannibalism (Osawa 1992a). Taken together, increasing rearing density without decreasing pre-imaginal development appeared to be very difficult for the mass rearing of coccinellids larvae, like $H$. axyridis (Omkar and Pathak 2009). In addition, $H$. axyridis larvae, especially the 4th instar, are highly voracious (Paul et al. 2015) and take a long period to complete their development. For example, fed on the pea aphid, Acyrthosiphon pisum (Harris) (Hemiptera: Aphididae), the mean duration of each stage of $H$. axyridis at $26{ }^{\circ} \mathrm{C}$ was 2.5 days for the 1 st instar, 1.5 days for the 2nd instar, 1.8 days for the 3rd instar, and 4.4 days for the 4th instar (LaMana and Miller 1998).

It has been shown that rearing density of several coccinellid species could be increased with the units that provide refuges (i.e., hiding places) (Riddick and Wu 2015). Thus, mass rearing of $H$. axyridis larvae, with a high density, would be achieved by designed obstructs in rearing units that can decrease larval-larval or larvalpupal encounter frequency.

In this study, three types of obstructs were first designed and used in plastic Petri dishes rearing units. The rearing efficiencies were evaluated by mix populations of the cowpea aphid, Aphis craccivora Koch and the pea aphid, A. pisum (Hemiptera: Aphididae). After that, the optimal type was selected out and used for determining the potential for a high-density rearing of $H$. axyridis.

\section{Methods}

\section{Insects}

The ladybird beetle, $H$. axyridis was obtained from continuous rearing colony in the laboratory and reared on the mix population of $A$. craccivora and A. pisum. The two co-infested aphids were collected from field and maintained on the broad bean seedlings. All insects were maintained in an insectary $\left(25 \pm 1^{\circ} \mathrm{C}, 60 \% \mathrm{RH}\right.$, and 16:8 L:D). Three pairs of newly emerged adults were reared in a plastic Petri dish unit $(9 \mathrm{~cm}$ in diameter, $1.5 \mathrm{~cm}$ high; BKMAM, China) and supplied with sufficient aphids as food and 2 broad bean leaves for oviposition. The daily eggs produced were incubated in a new Petri dish for 3 days with an immersed cotton ball for keeping moisture. Egg hatching was monitored with an interval of $12 \mathrm{~h}$, and the neonate larvae were collected for subsequent rearing.

\section{Design of obstructs}

It was assumed that the larval movement and the larvalarva encounter of $H$. axyridis could be restricted at different degrees with obstructs so that the cannibalism could be reduced. In order to evaluate their efficiency in reducing cannibalism, in this study, three different patterns of obstructs (polyvinyl chloride) were designed (Con-A, Con-B, and Con-C, Fig. 1) and equipped in transparent plastic Petri dishes (polystyrene, $9 \mathrm{~cm}$ in diameter and $1.5 \mathrm{~cm}$ high with the total volume of 95.38 $\mathrm{cm}^{3}$ ) as rearing units (Fig. 1). The obstructs were made from pieces of transparent plastic strips $(1.5 \mathrm{~cm}$ in width, $8.9 \mathrm{~cm}$ in length, and $0.05 \mathrm{~cm}$ in thickness). The design of the Con-A obstruct was from the inspiration of maze which provides many refuge spaces. The Con- $B$ obstruct provided many quadrate divisions $(1.5 \times 1.5$ $\mathrm{cm})$. The Con-C obstruct had 16 divisions with radial strips connected with another strip on the central section, and it had less restriction for larval movement than the Con-B obstruct. The Con-B and Con-C obstructs had insect passing holes (equilateral triangle in shape with $0.5 \mathrm{~cm}$ in length of side) on each side. The obstructs were glued together by a hot melt adhesive and each placed into a plastic Petri dish as a complete rearing unit. The surface area of Con- $\mathrm{A}$, Con- $\mathrm{B}$, and Con- $\mathrm{C}$ units was approximately $291 \mathrm{~cm}^{2}, 495 \mathrm{~cm}^{2}, 312 \mathrm{~cm}^{2}$, respectively, and the surface area of the empty plastic Petri dish (control) was approximate $106 \mathrm{~cm}^{2}$.

\section{Larval rearing with different units}

Sixteen newly hatched $H$. axyridis first instar larvae were gently transferred into one rearing unit and supplied with sufficient $A$. craccivora and $A$. pisum. The aphids were daily refreshed with an approximate weight of 180, 240, 400, and $1000 \mathrm{mg}$ for 1st, 2nd, 3rd and 4th instar larvae, respectively. Number of survived individuals as well as their development stages were checked and recorded daily until all adults emerged. Percentage of survived individuals in each unit was calculated against the total number of beetles in the unit. After feeding and recording, the unit was sealed by a parafilm $(1.2 \mathrm{~cm}$ in width) to avoid insect escaping. After pupation (all pupation finished on day 13 after rearing), the distribution of pupae on each surface of the unit (bottom, lid, and wall of the Petri dish and on obstructs) was recorded. Eight replicates were conducted for each type of the rearing unit.

\section{Evaluation of the potential for high-density rearing}

In this experiment, 16, 24, or 32 neonate larvae were respectively transferred to one Con-C equipped unit with the density of $0.168,0.252$, and 0.336 larvae $/ \mathrm{cm}^{3}$, respectively (abbreviated as $16-\mathrm{L}, 24-\mathrm{L}$, and $32-\mathrm{L}$ density, respectively). At 16-L density, similar number of aphids was provided as described above, while approximate 1.5 and 2 times more aphids were respectively provided to 24- $\mathrm{L}$ and 32-L density. The above number of aphids would be sufficient for high-density rearing of $H$. 


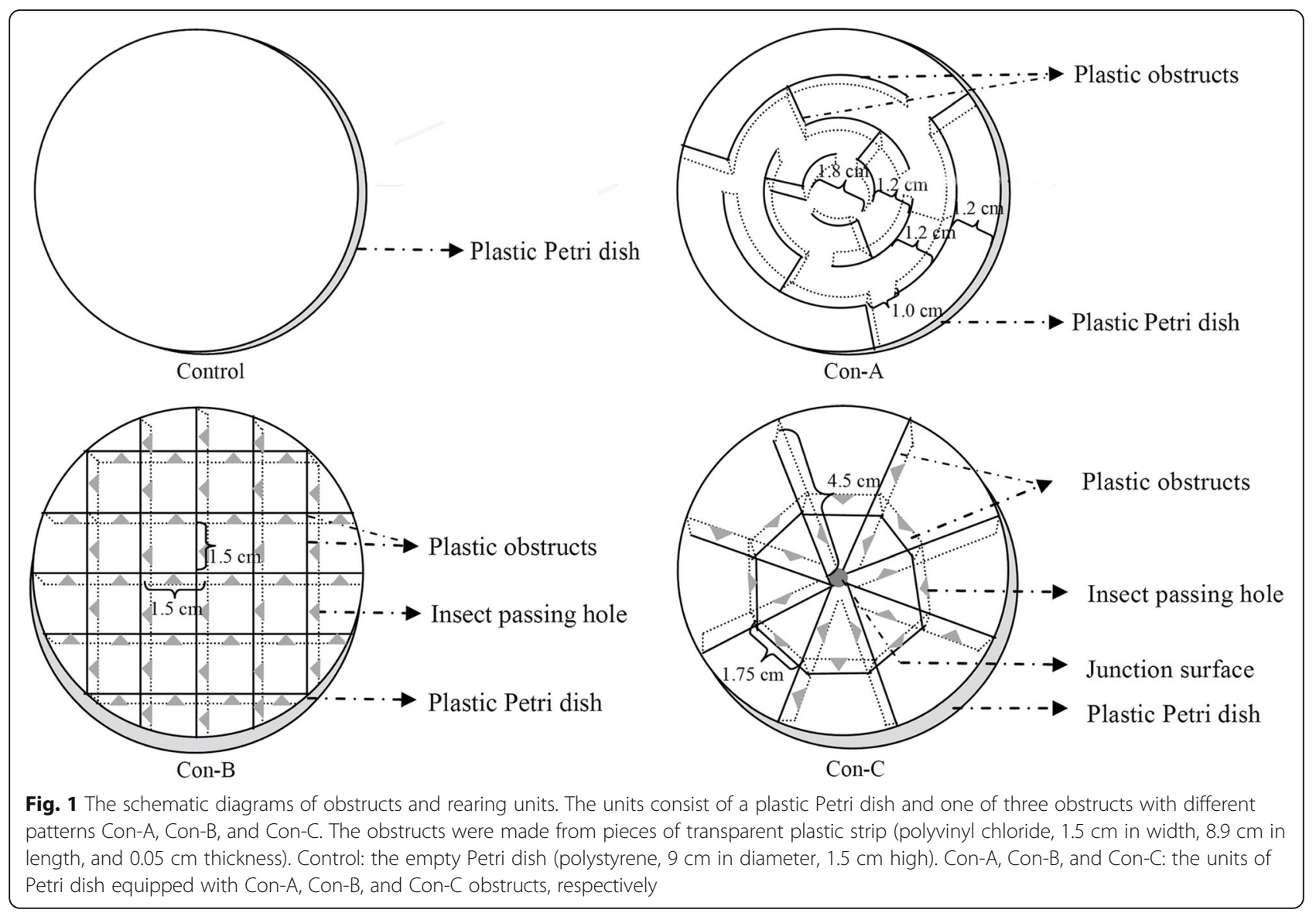

axyridis as that the predation rates of aphids showed to be decreased with rearing density (Gao et al. 2020). Once adult emergence started, the number of adults emerged in each day was recorded and calculated as percentage relative to the total number larvae tested with the following equation: (number of adults emerged)/ (total number of adults obtained) $\times 100$ ). The weight of newly emerged adults (24-36 h old) was measured using an AE224C electronic balance (SDPTOP, China) with an accuracy of $0.1 \mathrm{mg}$, and the female and male ratio was recorded. Ten replicates were conducted for each rearing density.

\section{Data analysis}

All data analysis was performed using SPSS 19.0 statistical software. The differences among different treatments were analyzed with one-way analysis of variance (ANOVA) for the data that met the assumptions of normality (Levene's test). For the data that failed to meet the assumptions of normality, the non-parametric Kruskal-Wallis analysis of variance (K-W ANOVA) was used. Means were separated with Tukey HSD test $(P<$ $0.05)$. The comparison between the observed sex ratio and the expected one (1:1) was conducted by the chisquare test. For 24-L and 32-L densities, the difference of the percentage of adults emerged at day 5 were compared with independent sample $t$ test $(P<0.05)$.

\section{Results}

\section{Screening of obstructs}

Under the density of 16 larvae per unit, the survival of the larvae that reared in the units with either the Con-A or the Con-B obstruct was non-significantly different from that reared in the control unit (Petri dish without any obstructs), while it was significantly higher with the Con- $C$ unit from day 5 (3rd and 4th day: $\chi^{2}=1.8$ and $3.4, P=0.332$ and 0.621 ; the remaining days: $\chi^{2}=10.2-$ 13.9, $P=0.003-0.017$ ) (Fig. 2A). The larval survivals tended to be stable from day 8 in the units with obstructs. However, the larval survivals in the control unit decreased sharply throughout the whole rearing periods and also decreased faster than those in the units with obstructs (Fig. 2A). Consequently, the percentage of larvae that survived to adult in the Con- $\mathrm{C}$ units $(74.2 \%$ of 16 neonate larvae) was significantly higher than the control (39.8\% of 16 neonate larvae) $\left(\chi^{2}=13.2, P=0.004\right)$ and also relatively higher than those in the Con-A and Con-B units (Fig. 2B).

In the control units, more than $80 \%$ pupae were distributed on the bottom of the Petri dish. However, in 

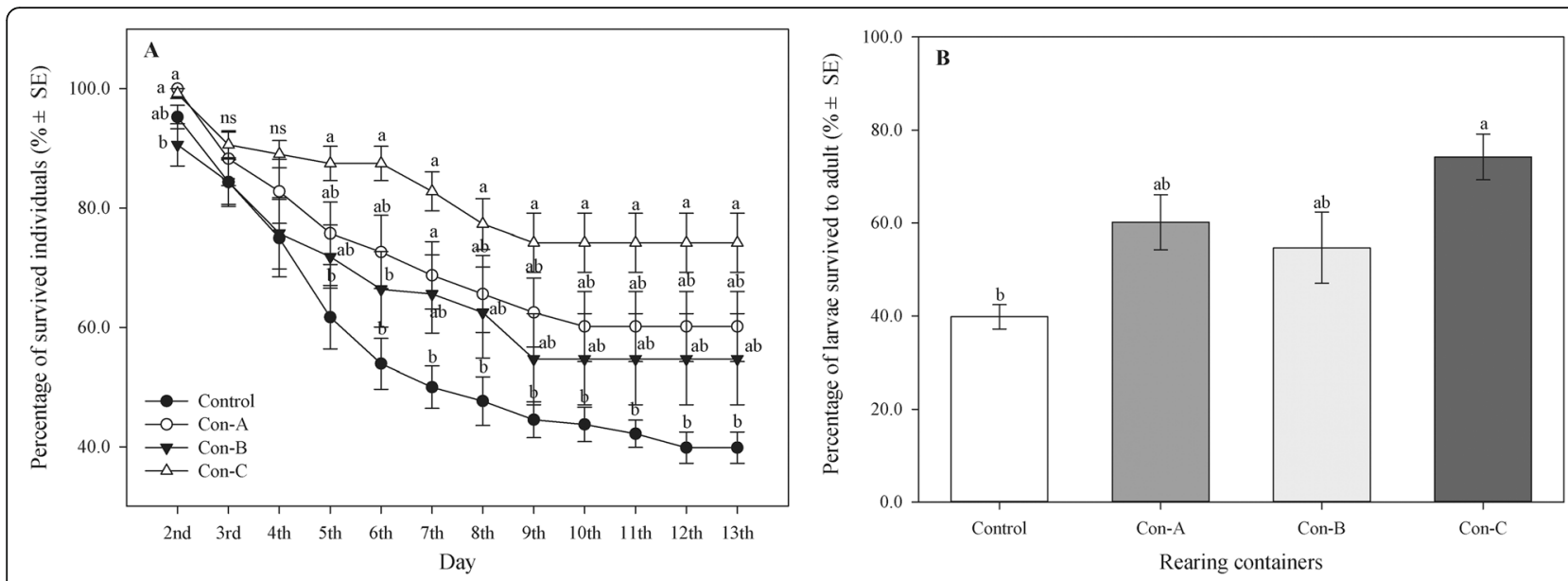

Fig. 2 Larval survival rate throughout the rearing periods until pupation (A) and to adulthood (B). Individual pupation started at the 8th day after rearing and all larvae entered pupal stages at the 13th day after rearing. Different letters indicated significant differences of the percentage of survived individuals among the four types of rearing units on the same day, ns indicates no significant difference $(\mathbf{A})$; different letters indicated significant differences of the percentage of larvae survived to adult among the four types of rearing units (B)

the Con- $\mathrm{A}$, Con- $\mathrm{B}$, and Con- $\mathrm{C}$ units, significantly more larvae selected obstructs as pupation sites than those selected the bottom, lid, and wall of the Petri dish $\left(X^{2}=\right.$ 13.6-26.2, $P<0.001$ ) (Fig. 3A). The typical distribution of pupae in the Con-C unit was shown in Fig. 3B, with an average of $58.92 \%$ on obstructs and $41.08 \%$ (sum of the data from bottom, wall, and lid) on the Petri dish.

\section{Evaluation of density-dependent rearing efficiency}

When 16, 24, and 32 neonate larvae per unit were reared in the Con-C units, which produced the best larval survival (Fig. 2), non-significant difference in the survival percentage was detected during the first 7 days $\left(F_{2,27}=\right.$ 1. 5-3.4, $P=0.050-0.250)$. Until pupation is finished, the larval survivals at the $16-\mathrm{L}$ density were significantly higher than those at the 24-L density $\left(\chi^{2}=6.7-8.7, P=\right.$ 0.013-0.035), and the larval survivals at the 32-L density were non-significantly different from either. Finally, average number of pupae were observed as $13.2(82.5 \%$ of 16 neonate larvae), 15.0 ( $62.5 \%$ of 24 neonate larvae), and $22.4(70.0 \%$ of 32 neonate larvae) at the $16-\mathrm{L}, 24-\mathrm{L}$, and 32-L density, respectively, on the 13th day. In addition, the survival percentages decreased sharply during the first 8 days, and stabilized afterward at all densities (Fig. 4A). At the rearing density of 32-L, the typical distribution of pupae was shown in Fig. 4B with an average of $82.2 \%$ on obstructs and $17.8 \%$ on Petri dish (sum of the data from bottom, wall, and lid). Almost all pupae
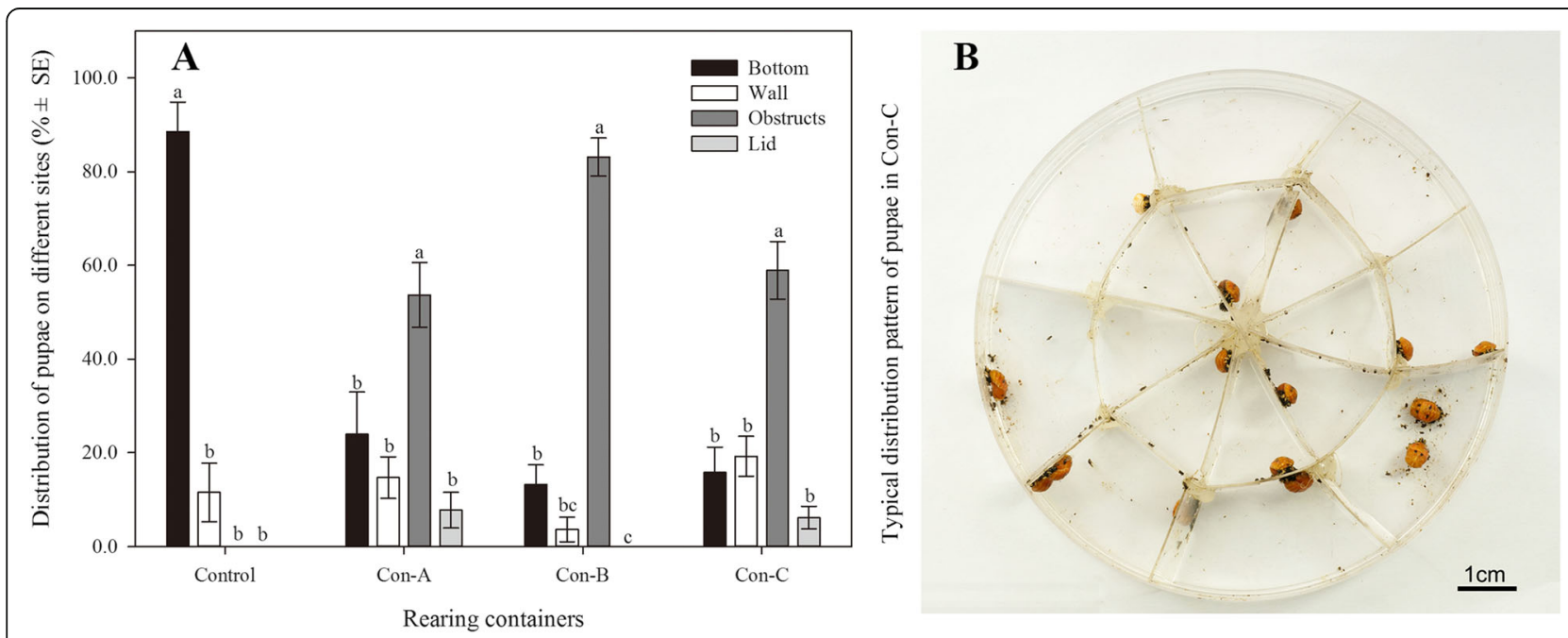

Fig. 3 Distribution of pupae in the four types of rearing units $(\mathbf{A})$ and the typical distribution pattern of pupae in the Con-C unit (B). Different letters indicated significant differences among the four sites (bottom, wall, and lid of Petri dish, on obstructs) of each type of rearing unit 


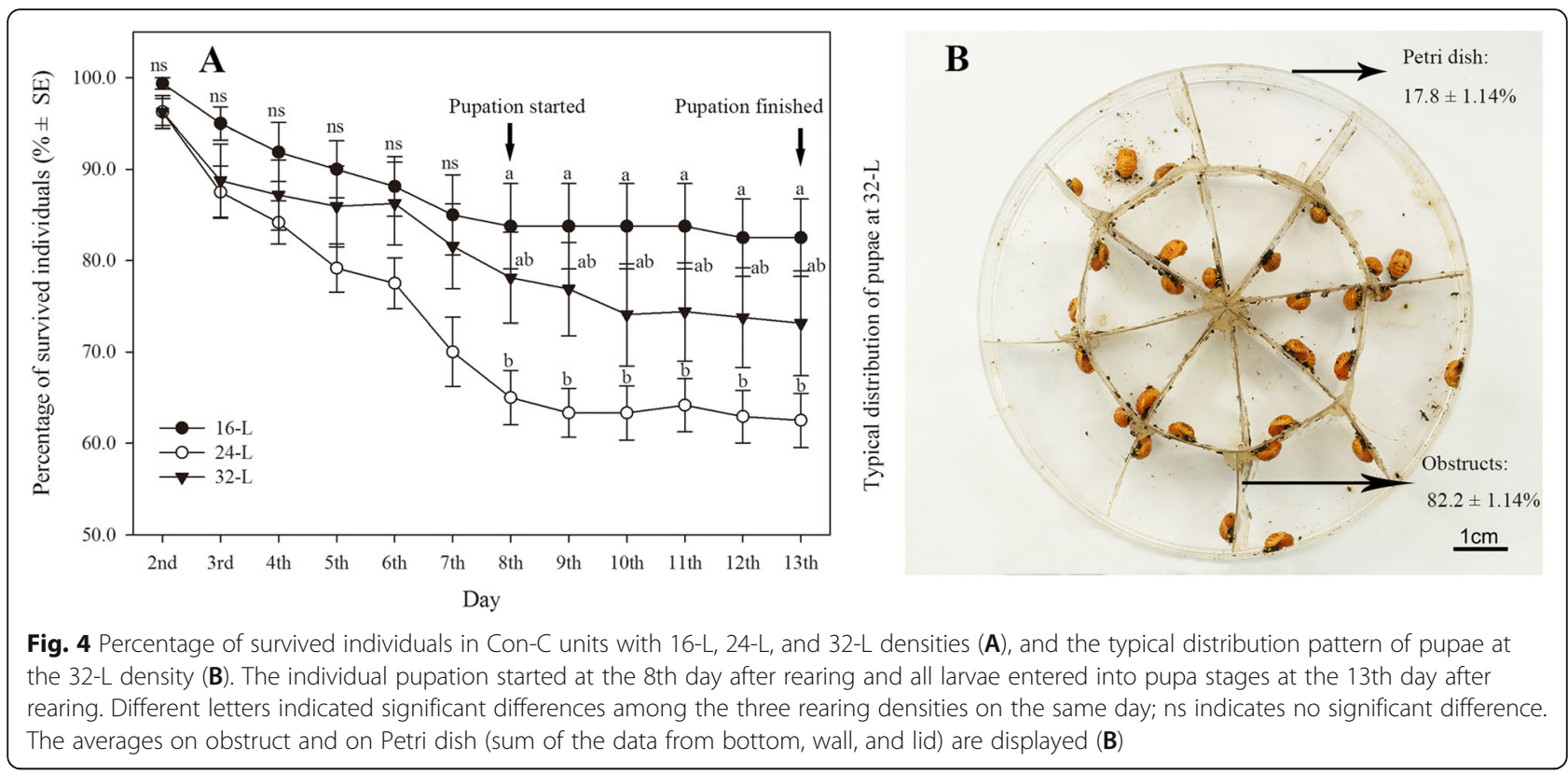

successfully developed to adult, so adult emergence rate was not separately recorded again and assumed that all pupae developed to adults.

At the 16-L density, the adult emergence lasted for 4 days and nearly equally distributed in each day (relatively lower at day 4$)\left(F_{3,36}=1.7, P=0.178\right)$. However, at either the 24-L or the 32-L density, the adult emergences lasted for 5 days. In addition, at the 2 higher densities, relatively higher proportions of adults emerged during the first 3 days, which were significantly higher than those on the 5th day (24-L: $F_{4,45}=6.5, P<0.001 ; 32-\mathrm{L}$ : $X^{2}=23.4, P<0.001$ ) (Table 1$)$. On day $1-4$, the adult emergence percentages at the 3 rearing densities were similar $\left(F_{2,27}=0.026-0.571, P=0.571-0.974\right)$. On day 5 , non-significant difference in adults' emergence was detected between the rearing densities of $24-\mathrm{L}$ and $32-\mathrm{L}$ $(t=-0.077, \mathrm{df}=18, P=0.939)$ (Table 1$)$.

For the newly emerged adults, the weights of both females and males were significantly higher at the 16-L density than those at the $24-\mathrm{L}$ and the $32-\mathrm{L}$ density (female $F_{2,192}=8.5, P<0.001$; male $F_{2,180}=6.1, P=$ $0.003)$, but there was non-significant difference in the adults' weights between the latter 2 densities (Fig. 5). In addition, at the densities of $16-\mathrm{L}$ and $24-\mathrm{L}$, relatively

Table 1 Percentage of adults emerged at different periods and the ratio of females and males, with an expected ratio of 1:1

\begin{tabular}{|c|c|c|c|}
\hline \multirow{2}{*}{$\begin{array}{l}\text { Adult emergence } \\
\text { period }\end{array}$} & \multicolumn{3}{|c|}{ Rearing densities } \\
\hline & 16-L & 24-L & $32-\mathrm{L}$ \\
\hline & \multicolumn{3}{|c|}{ Percentage of adults emerged (\%) } \\
\hline Day 1 & $29.84 \pm 6.4 \mathrm{Aa}$ & $32.31 \pm 5.78 \mathrm{Aab}$ & $28.39 \pm 6.20 \mathrm{Aab}$ \\
\hline Day 2 & $31.22 \pm 6.9 \mathrm{Aa}$ & $33.69 \pm 5.45 \mathrm{Aa}$ & $29.43 \pm 4.95 \mathrm{Aa}$ \\
\hline Day 3 & $28.00 \pm 6.39 \mathrm{Aa}$ & $18.60 \pm 5.84$ Aabc & $25.77 \pm 2.98 \mathrm{Aab}$ \\
\hline Day 4 & $13.73 \pm 4.05 \mathrm{Aa}$ & $12.30 \pm 5.70 \mathrm{Abc}$ & $13.15 \pm 3.26 \mathrm{Abc}$ \\
\hline \multirow[t]{2}{*}{ Day 5} & & $3.11 \pm 1.30 \mathrm{AC}$ & $3.26 \pm 1.43 \mathrm{Ac}$ \\
\hline & \multicolumn{3}{|c|}{ Female and male ratio } \\
\hline Number of females & 57 & 63 & 79 \\
\hline Number of males & 43 & 52 & 87 \\
\hline$x^{2}$ & 1.960 & 1.052 & 0.386 \\
\hline$P$ & 0.162 & 0.305 & 0.535 \\
\hline
\end{tabular}

Different lowercase letters indicate significant differences in the percentages of adults emerged at different days; same uppercase letters indicate no significant difference among different rearing densities at each adult emergence period $(P<0.05)$ 


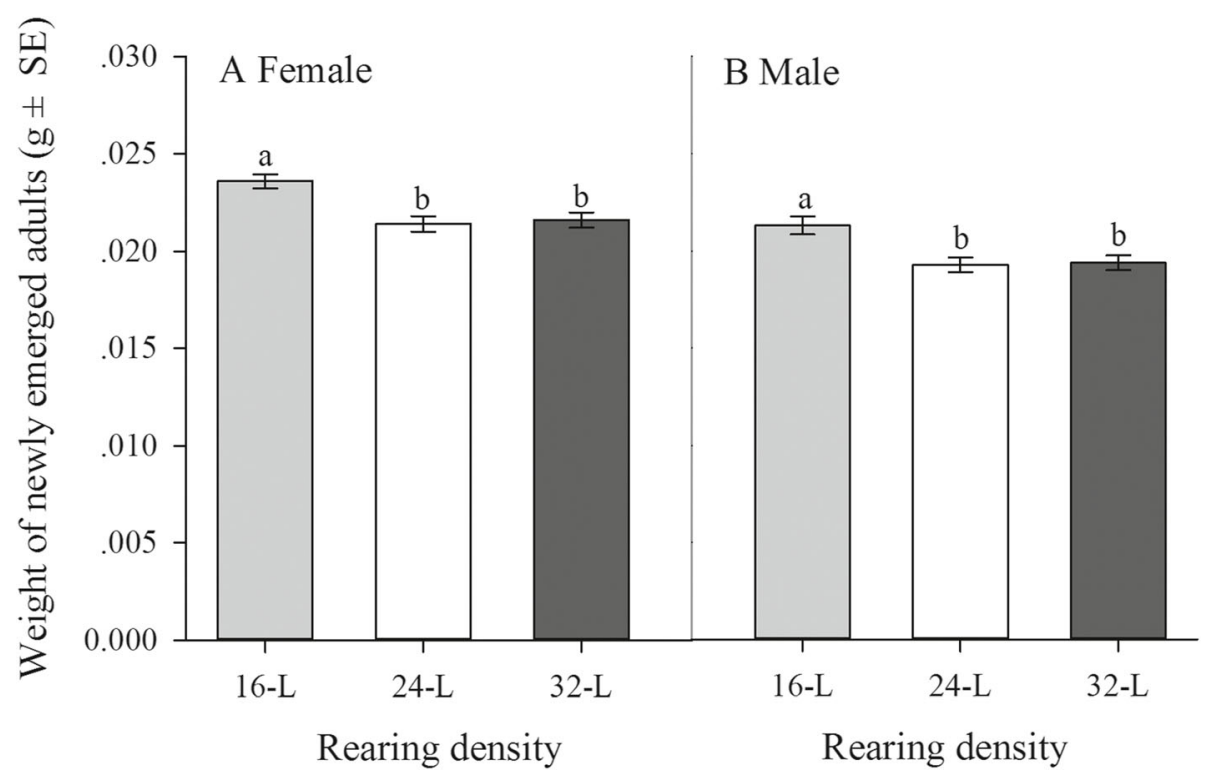

Fig. 5 Weights of newly emerged female (A) and male (B) adults. Different letters indicated significant differences among the three rearing densities

more females were harvested than males, but more males were harvested than females at the $32-\mathrm{L}$ density. Even so, at the three rearing densities, the female and male ratio was non-significantly different from the expected ratio of 1:1 (Table 1).

\section{Discussion}

As expected, providing obstructs as a part of rearing units can effectively improve the survival of $H$. axyridis larvae, which have genetic inheritance for the propensity of cannibalism (Wagner et al. 1999). Survival rate decreased sharply with time in the rearing unit without any obstruct, but it decreased moderately in the unit equipped with obstructs, indicating a decrease of the cannibalism of $H$. axyridis by using the obstructs. Specially, throughout the whole rearing periods, the larval survivals in the unit equipped with Con-C obstruct $\left(312 \mathrm{~cm}^{2}\right)$ were relatively higher than those in the units with either decreasing the surface area to $291 \mathrm{~cm}^{2}$ by the Con-A obstruct or increasing the surface area to 495 $\mathrm{cm}^{2}$ by the Con-B, demonstrating the efficiency of obstructs was a pattern-dependent rather than surface area (Mamay and Mutlu 2019). Such results might be caused by some unrevealed behaviors of $H$. axyridis larvae, and more studies, e.g., video monitoring, need to be conducted to fully reveal the mechanism. Finally, the rate of individuals reaching to adult increased from $39.8 \%$ in empty Petri dish (control unit without any obstructs) to $74.0 \%$ in the unit equipped with the Con-C obstruct, when the initial larval density was 16 . In this study, the adult survival rate without any obstructs (39.8\% at 0.168 larvae $/ \mathrm{cm}^{3}$ ) was lower than $46.7-53.8 \%$ that reported by Sun et al. (2019) under similar densities (0.15 larvae $/ \mathrm{cm}^{3}$ ), where $H$. axyridis larvae were fed on the eggs of the Mediterranean flour moth, Ephestia kuehniella Zeller (Lepidoptera: Pyralidae). For H. axyridis, Reznik et al. (2017) reported that the green peach aphid, Myzus persicae (Sulzer) (Hemiptera: Aphididae) was more easily to cause densitydependent effects than the eggs of the grain moth, Sitotroga cerealella (Olivier) (Lepidoptera: Gelechiidae). Thus, prey type might be also an important factor affecting rearing efficiency, and in the future, optimal prey should be considered to further improve the efficiency of high-density rearing with the Con- $\mathrm{C}$ unit.

The studies on coccinellids showed that motionless larvae when molting or partially immobile late 4th instar larvae were most easily attacked by the siblings (Riddick and Wu 2015). However, $H$. axyridis 4th instar larvae were reported to exhibit an avoidance behavior for cannibalism as they tend to avoid conspecific larvae in the olfactometer choice experiments (Rasekh and Osawa 2020). Here, the larval-larval or larval-pupal encounter frequency would be greatly decreased by provisioning the obstructs (pattern-dependent) that can provide more suitable habitats for both ladybird beetle and aphids crawling and roosting, as well as more pupation sites. Significantly more proportion of pupae distributed on the obstructs than on the Petri dishes partially supports the speculations. Osawa (1992b) reported that $14.4 \%$ of newly molted $H$. axyridis pupae would be cannibalized at the pupal stage. The larvae of $H$. axyridis, especially the 4th instar were voracious predators. Under highdensity conditions, a high-intraspecific competition would be occurred when the larvae reached to 4th instar 
due to their voracious behaviors (Paul et al. 2015). Thus, provisioning of obstructs, i.e., increasing the inner surface area and acting as the refuges for larvae and newly molted pupae, would be particularly important for reducing cannibalism in $H$. axyridis.

In addition, with the Con-C obstruct, significantly higher larval survival rates were detected at the 16-L density $\left(0.168\right.$ larvae $\left./ \mathrm{cm}^{3}\right)$ than at the $24-\mathrm{L}$ density $\left(0.252\right.$ larvae $\left./ \mathrm{cm}^{3}\right)$, while at the $32-\mathrm{L}$ density $(0.336$ lar$\left.\mathrm{vae} / \mathrm{cm}^{3}\right)$, the survival rate was between those two and not significantly different from them. More importantly, under the 2 higher densities, a high proportion of individuals survived to adult stage $(62.5$ and $70.0 \%$ for $24-\mathrm{L}$ and 32-L, respectively). These results showed that, even under extreme high-rearing density, there was no clear density-dependent efficiency for larval survival of $H$. axyridis with the rearing unit equipped with Con-C obstruct. This phenomenon might be caused by the fact that $16-\mathrm{L}$ density was very high for the rearing unit with approximate $95.38 \mathrm{~cm}^{3}$.

Increasing population density in mass production of $H$. axyridis might also cause some non-lethal negative effects as the adults need more days for emergence at the $24-\mathrm{L}$ or $32-\mathrm{L}$ densities than those at the $16-\mathrm{L}$ density, and both females and males were also significantly lighter. It was speculated that these negative effects under higher rearing densities might be caused by the disturbance of normal metabolism. For Coccinella undecimpunctata L. and C. novemnotata Herbst (Coleoptera: Coccinellidae), their adult weights were also generally decreased by increasing of population density (Turnipseed et al. 2014). In addition, decreased weights under high-rearing density might be caused by the changes in feeding regime (feeding intensity) (Reznik et al. 2017) and by the more frequent mechanical interactions, resulting in the stimulation of defense reactions (hemolymph losses) (Sato et al. 2008) and then the negative effects (Bayoumy et al. 2019). Here, the sex ratios of newly emerged adults under all rearing densities were met with the expected ratio (1:1), which was similar to that reported in the three striped ladybird beetle, Brumoides suturalis (Fabricius) (Coleoptera: Coccinellidae) (Bista et al. 2012) and in the pink spotted ladybird beetle, C. maculata (Riddick and Wu 2015).

\section{Conclusions}

The obtained results demonstrated the principle of using purposely designed obstructs in reducing insect cannibalism and highlighted the effects of such obstructs on the improvement of the larval and pupal survival rates of the ladybird beetle $H$. axyridis. Similar rearing unit equipped with obstructs like the Con-C pattern could have great potential in mass-rearing of other natural enemies.

\section{Abbreviations}

Con-A, Con-B and Con-C: the units of Petri dish with Con-A, Con-B and ConC obstructs built-in, respectively; $16-\mathrm{L}, 24-\mathrm{L}$, and $32-\mathrm{L}$ : The rearing density of 16,24 , and 32 larvae in each Con-C unit, respectively

\section{Acknowledgements}

We are grateful for the assistance of all staff and students in the Biocontrol Engineering Laboratory of Crop Diseases and Pests of Gansu Province,

College of Plant Protection, Gansu Agricultural University, Lanzhou, China.

\section{Authors' contributions}

YXS planned the research project, wrote, revised, and edited the manuscript. YNH helped to conduct the experiments and wrote the manuscript. CZL and SSW supervised the research and helped to analyze the data. JJZ made critical revisions to the manuscript. All authors have read and agreed to the final version of the manuscript.

\section{Funding}

This research was financed by Funds of Biocontrol Engineering Laboratory of Crop Diseases and Pests of Gansu Province (BELCDP-2018-01), the National Natural Science Foundation of China (31960561), the Funds for Fuxi Young Scientific Talents of Gansu Agricultural University (Gaufx-03Y05), and the National Key Research and Development Program of China (2018YFD0200405). These funders supported the trips for collection insects and provided all materials used in preparation rearing units and rearing insects.

Availability of data and materials

The datasets generated and analyzed during the current study are available in the fgshare repository, https://doi.org/10.6084/m9.figshare.12581168.v2.

\section{Declarations}

Ethics approval and consent to participate

The materials used in this study were ethically approved and consent to participate was given.

\section{Consent for publication}

Not applicable.

\section{Competing interests}

The authors declare that they have no competing interests.

Received: 11 January 2021 Accepted: 4 May 2021

Published online: 10 May 2021

\section{References}

Bayoumy MH, Osawa N, Séverin H (2019) Fitness costs of reflex bleeding in the ladybird beetle Harmonia axyridis: the role of parental effects. Insect Sci 27(6): 1346-1359. https://doi.org/10.1111/1744-7917.12737

Bista M, Mishra G, Omkar (2012) Influence of crowding and diet on the development and survival of the ladybird Brumoides suturalis (Coleoptera: Coccinellidae) reared on two aphid species. Int J Trop Insect Sci 32(01):64-68. https://doi.org/10.1017/\$1742758412000057

Brown PMJ, Adriaens T, Bathon H, Cuppen J, Goldarazena A, Hagg T, Kenis M Klausnitzer BEM, Kovar I, Loomans AJM, Majerus MEN, Nedved O, Pedersen J, Rabitsch W, Roy HE, Ternois V, Zakharov IA, Roy DB (2008) Harmonia axyridis in Europe: spread and distribution of a nonnative coccinellid. BioControl 53(1):5-21. https://doi.org/10.1007/s10526-007-9132-y

Gao GZ, Liu SQ, Feng LK, Wang YL, Lu ZZ (2020) Effect of temperature on predation by Harmonia axyridis (Pall.) (Coleoptera: Coccinellidae) on the walnut aphids Chromaphis juglandicola Kalt. and Panaphis juglandis (Goeze) Egypt J Biol Pest Co 30(1):137. https://doi.org/10.1186/s41938-020-00337-7

LaMana ML, Miller JC (1998) Temperature-dependent development in an Oregon population of Harmonia axyridis (Coleoptera: Coccinellidae). Environ Entomol 27(4):1001-1005. https://doi.org/10.1093/ee/27.4.1001

Mamay M, Mutlu C (2019) Optimizing container size and rearing density for rapid and economic mass rearing of Oenopia conglobata (Linnaeus, 1758) (Coleoptera: Coccinellidae). Turk Entomol Derg-Tu 43(4):395-408 
Michaud JP (2003) A comparative study of larval cannibalism in three species of ladybirds (Coleoptera: Coccinellidae). Ecol Entomol 28(1):92-101. https://doi. org/10.1046/j.1365-2311.2002.00481.x

Mills NJ, Heimpel GE (2018) Could increased understanding of foraging behavior help to predict the success of biological control? Curr Opin Insect Sci 27:2631. https://doi.org/10.1016/j.cois.2018.02.013

Obrycki JJ, Kring TJ (1998) Predaceous Coccinellidae in biological control. Annu Rev Entomol 43(1):295-321. https://doi.org/10.1146/annurev.ento.43.1.295

Omkar PS (2009) Crowding affects the life attributes of an aphidophagous ladybird beetle, Propylea dissecta. B Insectol 62:35-40

Osawa N (1992a) A life table of the ladybird beetle Harmonia axyridis Pallas (Coleoptera, Coccinellidae) in relation to the aphid abundance. Jpn J Entomol 60:575-579

Osawa N (1992b) Effect of pupation site on pupal cannibalism and parasitism of the ladybird beetle Harmonia axyridis Pallas (Coleoptera: Coccinellidae). Jpn J Entomol 60:131-135

Osawa N (2002) Sex-dependent effects of sibling cannibalism on life history traits of the ladybird beetle Harmonia axyridis (Coleoptera: Coccinellidae). Biol J Linn Soc 76(3):349-360. https://doi.org/10.1111/j.1095-8312.2002.tb01702.x

Paul SC, Pell JK, Blount JD (2015) Reproduction in risky environments: the role of invasive egg predators in ladybird laying strategies. PLoS One 10(10): e0139404. https://doi.org/10.1371/journal.pone.0139404

Rasekh A, Osawa N (2020) Direct and indirect effect of cannibalism and intraguild predation in the two sibling Harmonia ladybird beetles. Ecol Evol 10(12): 5899-5912. https://doi.org/10.1002/ece3.6326

Reznik SY, Belyakova NA, Ovchinnikov AN, Ovchinnikova AA (2017) The influence of density-dependent factors on larval development in native and invasive populations of Harmonia axyridis (Pallas) (Coleoptera, Coccinellidae). Entomol Rev 96(9):1048-1053

Riddick EW, Wu ZX (2015) Effects of rearing density on survival, growth, and development of the ladybird Coleomegilla maculata in culture. Insects 6(4): 858-868. https://doi.org/10.3390/insects6040858

Roy HE, Brown PMJ, Adriaens T, Berkvens N, Borges I, Clusella-Trullas S et al (2016) The harlequin ladybird, Harmonia axyridis: global perspectives on invasion history and ecology. Biol Invasions 18:997-1044

Sato S, Jimbo R, Yasuda H, Dixon AFG (2008) Cost of being an intraguild predator in predatory ladybirds. Appl Entomol Zool 43(1):143-147. https://doi.org/1 0.1303/aez.2008.143

Sun L, Chen X, Zhang YX, Zhao LL, Lin JZ (2019) Effect of breeding density on adult harvest and fecundity of Harmonia axyridis Pallas. Chinese J Bio Control 35(1):15-19 (in Chinese with English abstract)

Turnipseed RK, Ugine TA, Losey JE (2014) Effect of prey limitation on competitive interactions between a native lady beetle, Coccinella novemnotata, and an invasive lady beetle, Coccinella septempunctata (Coleoptera: Coccinellidae). Environ Entomol 43(4):969-976. https://doi.org/10.1603/EN14043

van Lenteren JC (2012) The state of commercial augmentative biological control: plenty of natural enemies, but a frustrating lack of uptake. BioControl 57(1): 1-20. https://doi.org/10.1007/s10526-011-9395-1

van Lenteren JC, Bueno VHP (2003) Augmentative biological control of arthropods in Latin America. BioControl 48(2):123-139. https://doi.org/10.1 023/A:1022645210394

Wagner JD, Glover MD, Moseley JB, Moore AJ (1999) Heritability and fitness consequences of cannibalism in Harmonia axyridis. Evol Ecol Res 1(3):375-388

\section{Publisher's Note}

Springer Nature remains neutral with regard to jurisdictional claims in published maps and institutional affiliations.

\section{Submit your manuscript to a SpringerOpen ${ }^{\circ}$ journal and benefit from:}

- Convenient online submission

- Rigorous peer review

- Open access: articles freely available online

High visibility within the field

- Retaining the copyright to your article

Submit your next manuscript at $\boldsymbol{\nabla}$ springeropen.com 